\title{
Waste Management in Labrador and Northern Communities: Opportunities and Challenges
}

\author{
Catherine M.H. Keske \\ University of California-Merced \\ Morgon Mills \\ Labrador Institute, Memorial University of Newfoundland \\ Laura Tanguay \\ University of California-Merced \\ Jason Dicker \\ Labrador Institute, Memorial University of Newfoundland
}

\begin{abstract}
This article discusses the origin and management of waste in two Labrador communities, Happy Valley-Goose Bay and Nain, and results from the qualitative phase of a two-stage mixed methods research study. Results illuminate challenges and opportunities associated with waste management in northern communities. Like many regions across the Canadian North, the principal study area consists of a population centre surrounded by diffuse, rural, and Indigenous communities, multiple land uses, and complex governance considerations. We identify factors contributing to the accrual, management, and transport of solid waste in Labrador related to historical and ongoing colonialism. Among the considerations are military development and mobile labour forces that generate both industrial and household waste. A combination of remoteness and climate makes waste collection, storage, and transport costly and slows organic waste decomposition. Corrosion from municipally treated water generates excessive appliance waste. Limited local food production and remoteness from manufacturing and retail centres increases the consumption of disposable shipping materials. Despite these challenges, it is essential to simultaneously recognize the efforts of local grassroots initiatives to effectuate sustainable waste management. We conclude that communities may benefit from implementing synergistic waste management strategies to reduce costs and public health risks, and to concurrently recognize the practicalities of waste management in the North. Results of the qualitative research phase led to the selection of a priority waste stream, black spruce biomass cleared for the Muskrat Falls hydroelectric dam project, for an economic study in the project's quantitative research phase.
\end{abstract}

The Northern Review 47 (2018): 79-112 


\section{Introduction}

1.1 Waste in Labrador as an Outcome of Ongoing Colonialism

This study utilizes archival data, semi-structured interviews with community partners, an information meeting with a community grassroots organization, and a participatory action meeting to illustrate challenges and opportunities associated with waste management in the northern communities of Happy Valley-Goose Bay and Nain, Nunatsiavut, Labrador, Canada.

Although little to date has been written about waste management practices in Labrador, we assert that these communities exemplify contemporary waste systems throughout the Canadian and Circumpolar North, which have resulted from sustained, disruptive periods of contact with Europeans over centuries. As noted by Hird (2016), natural resource extraction and military developments designed for the greater good of Canada and its allies have created, particularly since the twentieth century, disproportionately negative impacts on the northern communities where organic and inorganic wastes have been left behind. Associated demographic pressures and social changes have also transformed local settlement patterns and consumption habits, replacing traditional economies and waste systems with those of Western capitalism.

The most prominent example of military legacy waste in the Canadian Arctic is that left by the Distant Early Warning (DEW) radar line, the construction of which asserted Canadian sovereignty and the right of the American military to operate in Canada's northern territories in order to defend southern Canada and the United States Lower 48, without respect for the Indigenous peoples who had been inhabiting the Arctic for millennia (Hird, 2016). In 1954 and directly following the Second World War, sixty-three temporary military settlements were erected across Alaska, the Canadian Arctic, Greenland, and Iceland to defend against potential Soviet attacks (Lajeunesse, 2007). Hird points to the DEW line as a "develop now, remediate later" project. Although the sites closed between 1963 and 1993, and modern radar stations operate less invasively, DEW line cleanup is far from complete and remnants of solid waste and toxic, hazardous chemicals linger in local ecosystems (Capozza, 2002). Despite piecemeal federal government commitments to remediation, in many instances the burden of these legacy wastes rests on local Indigenous communities (Government of Canada, 2017; INAC, 2005; INAC, 2014; INAC 2016). 


\subsection{Description of Study Area}

A map of the Labrador study region is presented in Figure 1. As shown in Figure 1, Labrador is a large $\left(269,134 \mathrm{~km}^{2}\right)$ coastal region in northeastern mainland Canada. Its climate is predominantly Subarctic in inhabited areas, with boreal forests broken by alpine and coastal barrens giving way to tundra in northern Labrador. The largest population centre $(10,227$ people, or 38\% of Labrador's population) is the Upper Lake Melville area around Happy Valley-Goose Bay in central Labrador (Statistics Canada, 2017), at the head of the Hamilton Inlet estuary, which drains the Churchill River and several other major watersheds. Despite its Subarctic designation, the area has warm summers, no permafrost, and an average frost-free period of 104 days (St. Croix, 2002).

Demographically, the region is majority Indigenous, with $52 \%$ of Happy Valley-Goose Bay's population reporting an "Aboriginal identity" (Statistics Canada, 2011), and larger Indigenous majorities in the three outlying communities of North West River (about 550 people) and Sheshatshiu Innu First Nation (a reserve of about 1,300 people), both $35 \mathrm{~km}$ to the north, and Mud Lake, a hamlet of about fifty people a few kilometres east and across the Churchill River. The Labrador Inuit Land Claims Area (Nunatsiavut) includes five northerly communities and some outlying areas, but not Happy Valley-Goose Bay or most of the rest of Labrador.

Although Labrador is home to three Indigenous peoples (Innu, represented by the Innu Nation; and two groups of Inuit, represented by the Nunatsiavut Government and NunatuKavut Community Council), all of which are represented in the case study areas of Upper Lake Melville and Nain, Indigenous waste management practices are not explicitly examined in this article. However, others have noted that contemporary waste disposal practices in northern Canadian Indigenous communities have led to environmental degradation that has negatively affected the cultural health of peoples who maintain a strong and sacred bond with the land (Bharadwaj et al., 2006; Waldron, 2015). We believe that this is also likely to be the case in Labrador. 


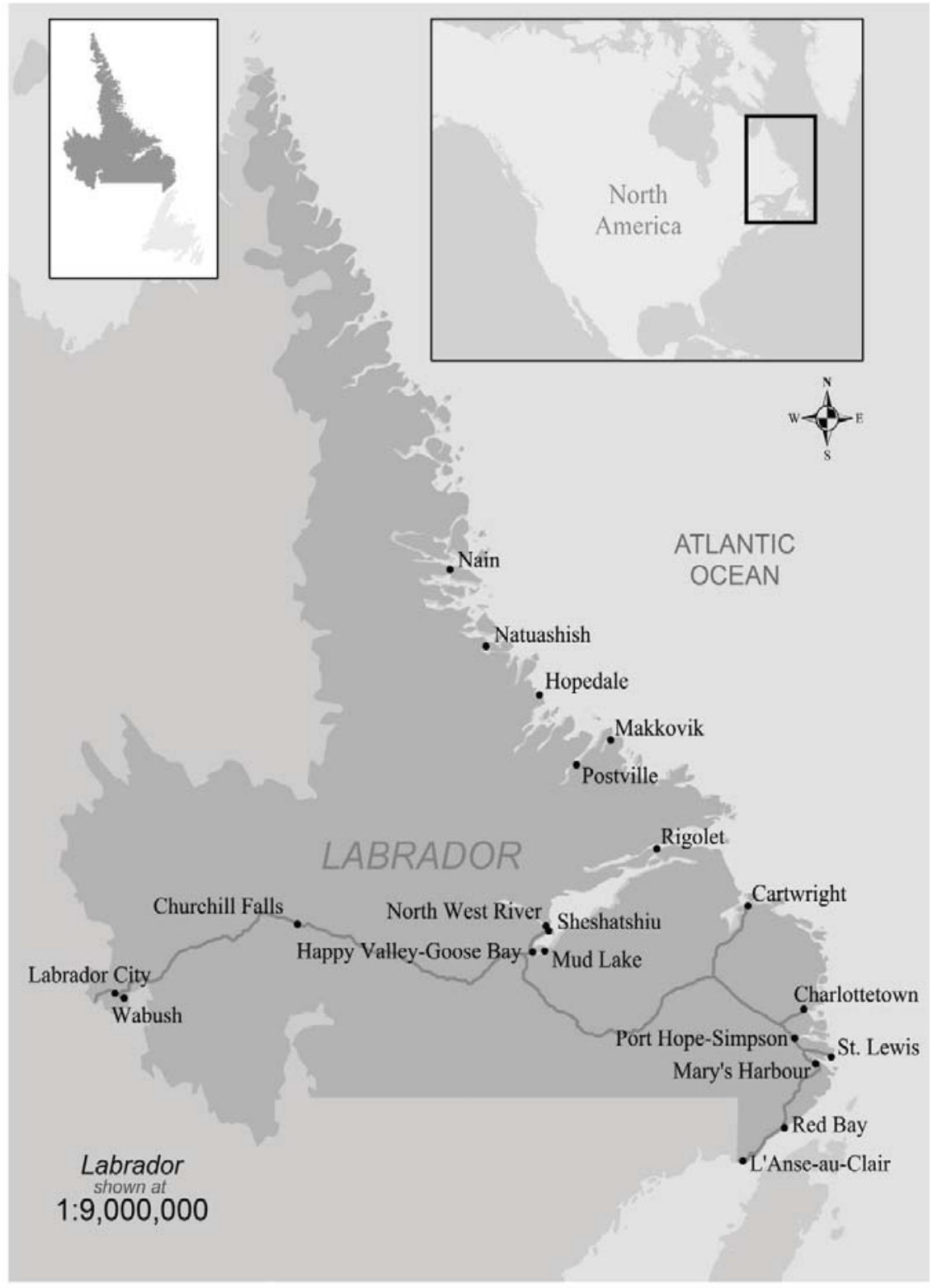

Figure 1. Map of Labrador. Nain, Hopedale, Makkovik, Postville, and Rigolet on the northern coast comprise Nunatsiavut; Natuashish and Sheshatshiu are Innu First Nations communities; and much of central and southeastern Labrador are NunatuKavut homelands. Cartography credit Myron King and Morgon Mills 


\section{Methods}

\subsection{Literature Review on Northern Waste and Mixed Methods Research}

The Labrador waste management study is situated as part of a larger multi-institutional, multidisciplinary project on facilitating sustainable communities and sustainable resources in the Arctic (ReSDA, 2018). Based upon a literature review of similar climates, we assert that we are the first to conduct a mixed methods study of waste in Labrador, although our project is, of course, motivated by the work of others. Several waste management studies have been conducted in similar climates within Europe, including Greenland (Eistead \& Christensen, 2013), Siberia (Starostina, Damgaard, Rechberger, \& Christensen, 2014), and other parts of northern Canada (Chouinard et al., 2014). Incineration and open dumping into unlined landfills are common practices in these rural regions. In addition to potential health impacts stemming from contaminated waste water and food sources, Czepiel et al. (2003) note that sanitary landfills are the leading anthropogenic source of methane emissions, which contribute roughly twenty-five times as much global warming potential as carbon dioxide. Most studies have looked at wastewater and have confirmed concerns about contamination.

Given the limited research specific to waste management in Labrador, as well as complex community governance considerations, we used a mixed methods research approach that facilitated the use of multiple methodologies and community-based data collection (Teddlie \& Tekkashore, 2009). Mixed methods research allowed us to assess and characterize the multiple waste streams in the region, and to assess community opinions through community partners and multiple qualitative approaches.

The methodology we employed was consistent with an integrative two-stage qualitative-quantitative research typology described in Teddlie and Tekkashore (2009). This article presents results from qualitative data collection conducted in 2016 and 2017 during the study's first research phase. Results from the qualitative phase were used to identify potential waste streams for a quantitative data analysis on the economic feasibility of a sustainable waste management solution within the study region. Results from the quantitative phase are available in Keske, Mills, Godfrey, Tanguay, \& Dicker (2018). 


\subsection{Qualitative Methodologies: Community-Based Participatory Research}

We employed a community-based perspective in all phases, beginning with a foundational partnership with the local municipality of Happy Valley-Goose Bay, the organization that initiated the underlying research project. This approach ensures that alternative, parallel, and intersecting waste management processes are included in the discussion.

The legacies of military waste and colonialism necessitate the use of community-based data collection methodologies, in part because waste management is one of many interrelated public systems for community well-being. This complex issue is therefore best understood from a perspective that takes a wide view of agency, including not only diverse municipal and high-level governmental structures, but also community values and practices. Community-based data collection approaches are adapted from well-established literatures on community health and well-being (e.g., Srinivasan, O'Fallon, \& Dearry, 2003; Parlee \& Furgal, 2012) and ecohealth (Charron, 2012). It is especially relevant in the context of northern and Indigenous communities, where governance systems and cultural practices may not conform with external structural paradigms (Zagozewski, Judd-Henrey, Nilson, \& Bharadwaj, 2011). Similar recognition in climate change studies has led to a broader appreciation of the importance of taking into account the interrelatedness of community systems, especially as they intersect with issues of community resilience (Ruscio, Brubacker, Glasser, Hueston, \& Hennessey, 2015), connectivity to the land (Cunsolo Willox et al., 2013), and the impacts of extractive resource development (Parlee, 2015; Southcott, 2015).

These issues make it important to review waste management as a comprehensive system while attaining information specific to Labrador. Hence, the scope of our study includes (yet expands beyond) waste practices in Indigenous communities, including Innu communities such as Sheshatshiu, Inuit communities such as Nain, and municipalities with large, mixed Indigenous populations, such as Happy Valley-Goose Bay.

Like others before us have shown, we assert that wastes and resources are inextricably linked, in that some costs associated with waste management may be recovered and transformed into opportunities. Identification of waste characteristics is a first step in actualizing any potential benefits, and it lays the groundwork for a cost-benefit analysis of specific waste streams. 


\subsection{Data Collection}

In the qualitative research phase, from March 2016 through June 2017, we obtained historical public records archived at the Town of Happy ValleyGoose Bay and within the Labrador Institute of Memorial University of Newfoundland. Data were collected and compiled from archival literature reviews and consultation with community partners. We also conducted semi-structured, participatory interviews and discussions with twentyone community partners, where at least one investigator asked a similar series of open-ended questions, and data were transcribed real time and clustered by themes (Keske, Hoag, McLeod, Bastian, \& Lacy, 2011; Creswell, 2003). Partners that have been affiliated with the project, all of whom directly work with community or municipal waste management processes or northern environmental conservation, are listed in the acknowledgements. Other partners, some of whom are involved with waste management through contracting or other research projects, were individually approached at the May 2017 Labrador Research Forum. In addition, we conducted a qualitative, participatory action meeting in May 2017 at the Labrador Research Forum, where approximately thirtyfive persons were invited to share their perspectives about challenges to northern waste management systems as part of an ideas generating session. This session was promoted as an opportunity to provide a context for dialogue about research addressing solid waste management issues, especially in rural and remote areas, by bringing together researchers, funders, and potential partners to brainstorm about already identified needs and research gaps, and to explore new possibilities specific to Labrador. Data from the Labrador Research Forum were recorded by two note-takers, and interview data were otherwise recorded by a single notetaker. These data were categorized by theme and the frequency by which they were raised. Following the Labrador Research Forum, we conducted an information meeting with the Happy Valley-Goose Bay Recyclers, a community grassroots organization. 


\section{Results}

\subsection{Historical Overview and Timeline of Happy Valley-Goose Bay Landfill}

One important outcome of the research is a timeline and historical overview of the Happy Valley-Goose Bay landfill, which serves as a specific example of military legacy waste, colonialism, and resource extraction. A timeline presented in Figure 2 tracks Labrador's rise and fall in population, relative to changes in resource extraction and defence infrastructure. This provides context for legacy military waste and socioeconomic community changes that influence waste management. The social changes summarized in Figure 2 are discussed throughout the results section.

Prior to the Second World War, waste management in central Labrador was simple, with middens for organic waste in settled communities, and a reliance upon natural decomposition processes among the Innu. With low populations, relatively little inorganic waste, and few potentially hazardous contaminants, waste management rarely posed major environmental, social, or economic problems. Even well into the twentieth century, as the region's population grew to several hundred through centralization, mineral exploration of the West, and other factors, the scarcity of raw materials and difficulty of import led to innovative reuse and recycling strategies, and most otherwise unusable or worn-out materials were burned for heat (Rich et al., 1984). However, as shown in Figure 2, the establishment of a military base at Goose Bay in 1941 introduced a wage economy and prompted in-migration of labour leading to rapid population growth and a shift away from traditional Indigenous and pre-industrial practices towards a series of disjointed, local waste management strategies.

The population of Happy Valley-Goose Bay increased considerably in the mid-twentieth century when its strategic position at the northeastern margin of the North American mainland made it a site of major military importance (Fraser, 2010). Goose Bay was the last stop west of the Atlantic on the Great Circle Route for air traffic to the European theatre of the Second World War, and as a consequence it was briefly the site of the largest airfield in the Western Hemisphere (Higgins \& Callanan 2006), and possibly the busiest airport in the world (Goose Bay Airport Corporation, 2018). As also shown in Figure 2, while the total population of the Canadian territories has steadily increased, for the most part, over the last century, Labrador's population peaked in the late 1960s and early 1970s - at the same time as the construction of the Churchill Falls hydroelectric station - then declined somewhat and stabilized. 


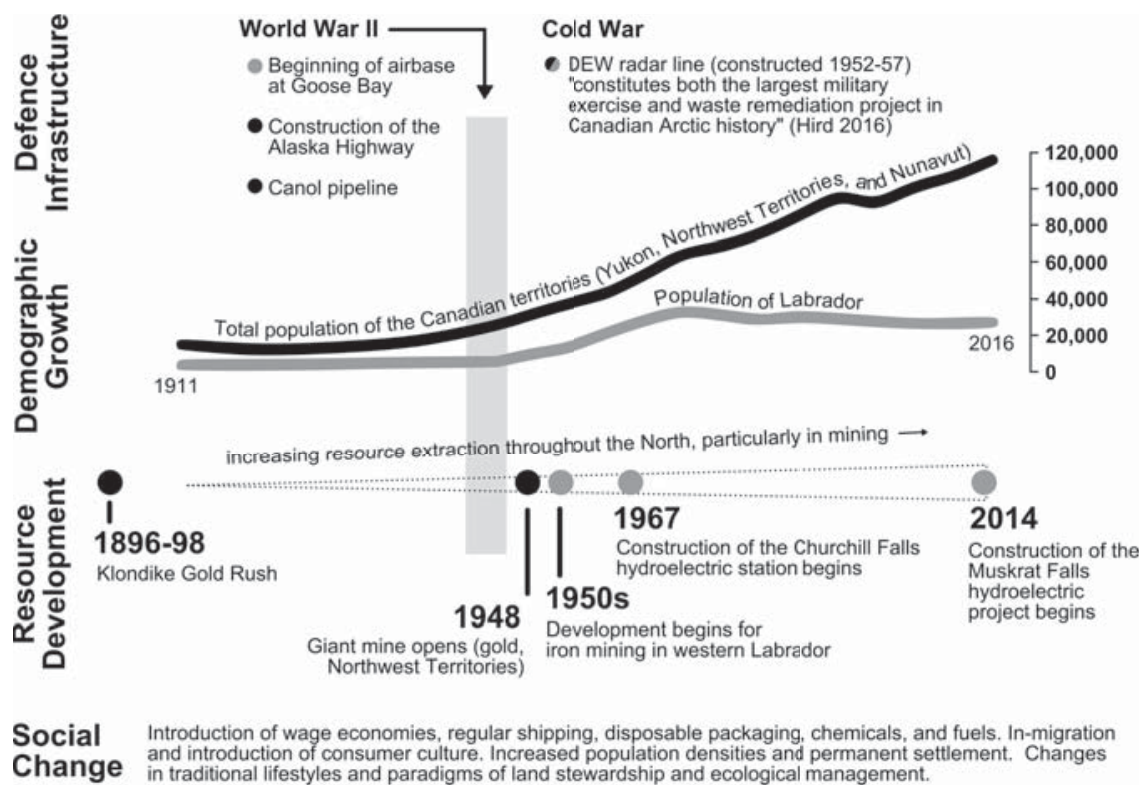

Figure 2. Defence infrastructure, demographic growth, resource development, and social change as colonial impacts on waste systems in Labrador and across the North.

As earlier discussed, following the war, the rise of tensions with the Soviet Union and the fear of attacks coming over the pole led to the American establishment of radar stations in defensive lines across Alaska, Canada, Greenland, and Iceland, including the DEW line, the massive scale and associated cleanup of which "constitutes both the largest military exercise and waste remediation project in Canadian Arctic history" (Hird, 2016). The DEW line included sixty-three radar stations across these nations. Of the forty-two DEW sites in Canada, twenty-one closed in the early 1960s, due to obsolescence, while the others continued operating under the Canadian Department of National Defence until the crewless, automated North Warning System (NWS) replaced them in 1993. These latter twenty-one sites underwent remediation by DND, which concluded in 2014, at a cost of approximately $\$ 575$ million (Department of National Defence, 2014).

Labrador's experience with the Pinetree Line, a series of radar stations stretching along the fiftieth parallel and the East Coast down into Quebec and southern Ontario, is closely analogous (Fletcher, 1990). Located at the northeastern limit of the line, Labrador had four manned radar stations, operational from 1953-Cartwright, Hopedale, and Saglek (all closed 
1968-1970), and the main location at Goose Bay (closed 1988) - as well as four smaller "gap filler" sites from 1957 to 1961 (Military Communications and Electronics Museum, 2002). Since 1941, Happy Valley-Goose Bay has also been the site of a major military airforce base, with the presence, at various times, of the Canadian, American, and British, and later Dutch, German, and Italian air forces, and it is now a Canadian Forces base. In Labrador, the most substantial, long-lasting environmental impacts of military development have been at Hopedale (Stantec, 2017), Saglek (DND, 2004), and Happy Valley-Goose Bay (DND, 2009), where thousands of kilograms of PCBs and other contaminants were released into local waters and soils, and expensive federal government remediation operations have been completed or are underway.

Changes in population and waste led to a series of different landfill locations that are illustrated in Figure 3. By 1976, both the Goose Bay (identified as " $\mathrm{C}$ " on Figure 3) and Happy Valley landfill sites (" $\mathrm{B}$ ") were identified as unsuitable locations due to pollution risks. The postamalgamation 1976 Happy Valley-Goose Bay Municipal Plan recommended regionalization to increase efficiency (1977). In 1980, however, the municipality continued to use a site slightly north of the original location east of town ("B"), burying the waste in boggy ground. The difficulty of winter filling was identified as a bigger issue than the need to find efficiencies (Happy Valley-Goose Bay Municipal Plan, 1981-1991). In the meantime, much of the military base used a former gravel pit at a new location (the topmost " $\mathrm{C}$ "), while the towns of North West River and Sheshatshiu used a separate landfill site nearer to their communities. The recommended combined Happy Valley-Goose Bay municipal landfill was opened at its current location in 1985, which is indicated by " $\mathrm{A}$ " in Figure 3 and depicted in an aerial photograph in Appendix A. The landfill now receives residential and commercial tipping from all three communities, while municipal contractors like Hickey Construction conduct weekly street-side pick up locally as well as in North West River and Sheshatshiu.

Not surprisingly, there are concerns about overflowing, with the location of several landfills and dumps near the Churchill River, Goose River, and Lake Melville. Due to logistical barriers, waste in Mud Lake continues to be incinerated and buried locally, despite periodic reexamination by provincial regulators (Felsberg, 2009). The Canadian Forces Base continues to dispose of waste in a number of sites, and the contents and locations are outside of community control. 


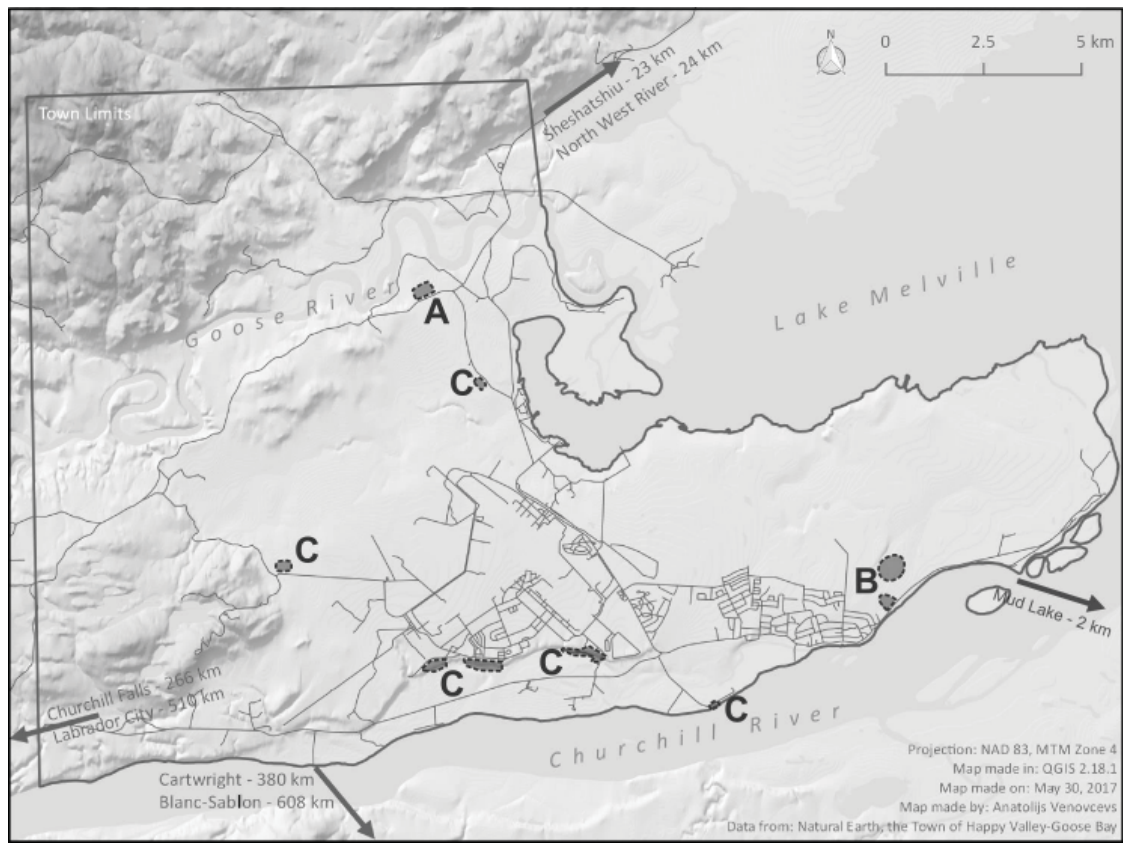

Figure 3. Map of Happy Valley-Goose Bay study region and landfill sites.

A: Current municipal landfill, opened 1985. B: Former Happy Valley dump sites.

C: Selected federal dump sites associated with 5-Wing Goose Bay air base.

Cartography Credit Anatolijs Venovcevs

\subsection{Waste Flows in Happy Valley-Goose Bay Study Region}

We now outline several sources of waste in the Happy Valley-Goose Bay study region that were identified during the qualitative research phase. These waste flows are illustrated in Figure 4.

Municipal waste is collected from dispersed locations and processed in a number of different ways; this is chiefly at the municipal landfill photographed and presented in Appendix A, as well as localized community recycling and waste recovery efforts. Scavenging is a reality in northern communities, as elsewhere, and this waste re-enters the waste flow after secondary household use. Waste from the large hydroelectric projects and military installations typically are processed separately, making it difficult for communities to achieve economies of scale.

Apart from the municipal landfill, solid waste in Happy ValleyGoose Bay is processed in various ways: by a Household Hazardous Waste Depot operated through the Multi-Materials Stewardship Board; by a provincially-contracted recycling depot for prescribed materials; by 
independent, commercial waste management contractors; by the health authority (hospital-generated medical wastes); through a municipal drop-off location for organic yard wastes; by commercial scrapyards; by a new municipally-run compost initiative; and by grassroots residentled strategies, such as composting, burning (including as heating fuel), reuse, unauthorized dumping and littering, and a new volunteer-led recycling initiative that pays for the trucking of household recycling to a plant in Newfoundland, showcasing both local residents' commitment to sustainable waste management, and the associated economic and logistical barriers.

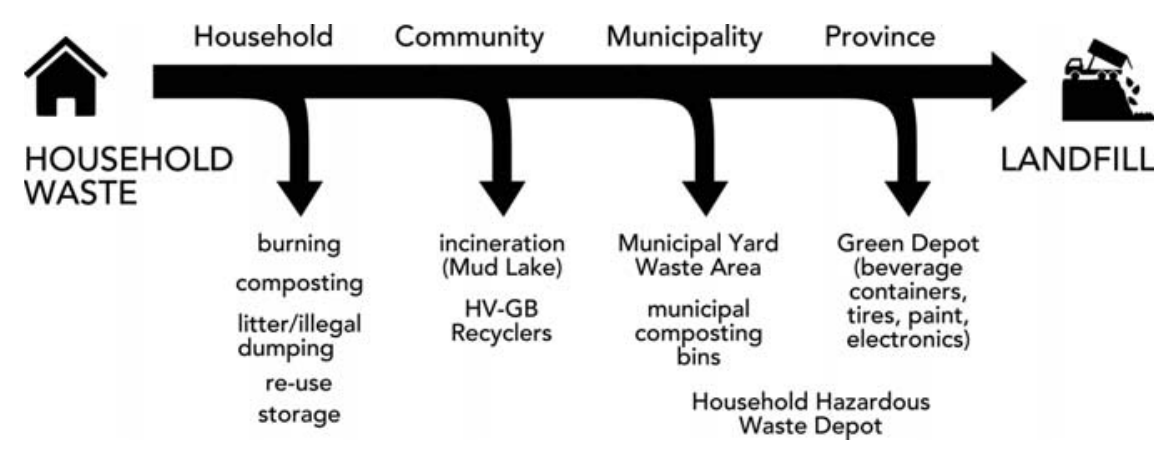

Figure 4(a). Major diversion pathways for municipal household waste in the Happy ValleyGoose Bay area.

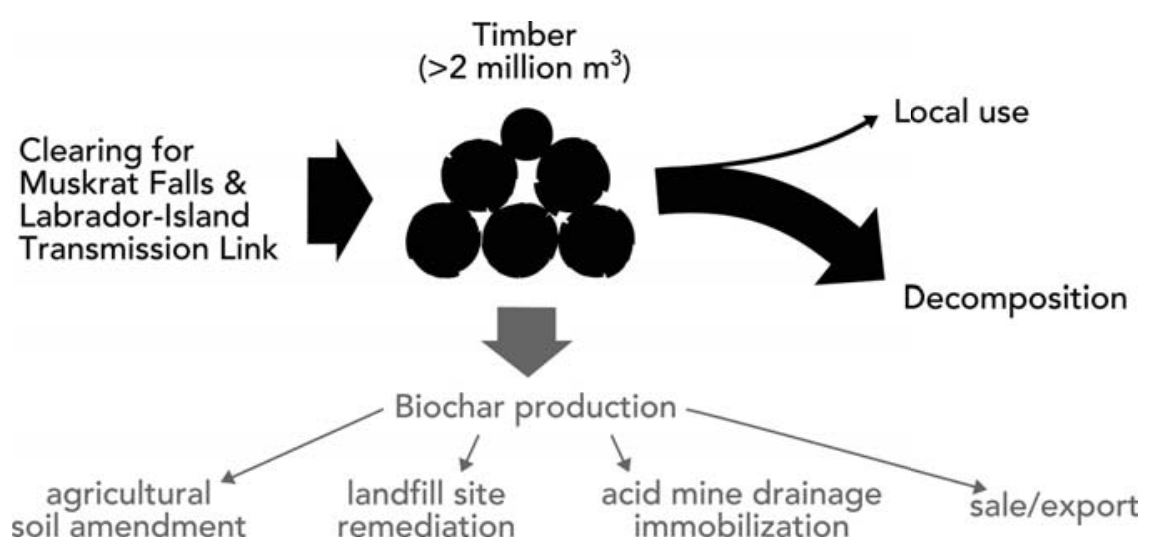

Figure 4(b). Pathway to repurpose waste biomass 
In Happy Valley-Goose Bay, the majority of household waste is bagged or boxed for weekly collection by the municipal contractor, Hickey Construction. Some residents choose to divert a portion of their wastes through various mechanisms, including reuse; home burning; composting (home, community group, or municipal initiatives); or recycling (home, community, or provincial programs), but there are also additional waste streams that are neither conveniently divertible nor eligible for street-side collection. Hazardous wastes, for example, are either stored indefinitely; illegally dumped; included in waste for street-side collection; or brought by residents directly to a processing site at the landfill gate, which is corun by the municipality and the provincial Multi-Materials Stewardship Board.

The most significant quantity of household waste is not collected weekly. It consists of items too voluminous to be bagged or boxed - such as demolition or renovation debris, yard waste, old appliances and furniture, and other bulky household items. Water-using appliances such as water heaters, washing machines, and dishwashers are particularly frequently discarded, given the medium-term corrosiveness of the municipallysupplied water (Fonkwe, 2016; Fonkwe and Schiff, 2016; CBC News, 2008). Our site visits of the municipal landfill confirm a large number of water heaters among a number of used appliances, though the rate at which these appliances are discarded compared to the rest of Canada has not been assessed, which may be a logical extension of our research.

Yard waste, general garbage, and appliances and scrap metal items are sorted separately, so that yard waste can be diverted, and metal items are kept at a distinct location in the landfill for later removal by scrap-metal companies that truck the material out of town along the Trans-Labrador Highway for recycling. As shown in Appendix B, furniture, appliances, construction debris, wood for burning, and spring cleaning are presented at the side of the curb as part of the annual "Spring Cleaning" recycling and collection event, and community members are encouraged to collect and transport items that they wish to reuse.

One of our major findings is that waste management in northern communities reflects waste accumulations generated by industries, like extraction, that became common across the North during the twentieth century. The waste flows from these industries have clearly affected Indigenous lands in a variety of ways, including direct impacts upon the hunting and harvesting of country foods to support their households. The presence of these industries has also effectively changed the social and cultural climate of the North, a topic that is being addressed by the 
overarching ReSDA project (2018). This has required waste management practices to evolve and adapt from those practised by Indigenous persons and early colonial settlers.

For example, in order to house workers for the development and operation of these large projects, some resource developments have established temporary camps (Muskrat Falls), permanent settlements (Churchill Falls), or created entirely new public municipalities (Labrador City). The population increases understandably raised the amount of household wastes produced, as noted in the Town of Happy Valley-Goose Bay's archives.

The autonomous governance and the scale of these large projects, coupled with an understandable need for confidentiality, results in the projects taking on their own waste management practices. In Spring 2017, Muskrat Falls began incinerating its own waste in response to an increase to landfill tipping fees.

The total volume of merchantable timber produced from forest clearing associated with the Muskrat Falls reservoir and transmission line has been estimated at 2,172,300 $\mathrm{m}^{3}$ (Nalcor, 2009, p. 10), but to date this substantial material resource has been underused. Some wood has been made freely available for domestic use by residents of Happy Valley-Goose Bay, North West River, and Sheshatshiu (Nalcor, 2015), but as frequently reported in the media (e.g., Canadian Press, 2014), the cost of transport has been a major barrier for initiatives to commercialize the resource.

In addition to the legacies of contamination left by formerly unregulated landfilling and the leakage of petrochemicals documented at Hopedale, Saglek, Cartwright, and other military installations in Labrador, the military base at Goose Bay has an enduring involvement in waste management processes. The military bases have included Canadian, American, and North American Treaty Organization (NATO) troops that provide governance over military waste streams and cleanup with mixed success. It is not uncommon for military personnel to join Labrador communities once they complete their military service. The military bases have gradually scaled back their operations in recent decades, which has resulted in some demolition waste. As is common with many military installations, their waste management practices have not been overtly transparent to the public, although the Department of National Defence and the Canadian Armed Forces, which supplies the community of Happy Valley-Goose Bay with a grant in lieu of property taxes, uses the municipal landfill to some extent. 
Not surprisingly, along with the economy and lifestyles, food consumption patterns have also changed correspondingly. Several at-risk communities have a higher consumption of pre-packaged foods (Schiff and Bernard, 2018), which is associated with lower income households. The municipality and waste collection service providers that are part of our collaborators have noted a higher incidence of food packaging waste in lower income communities compared to the rest of the community as a whole (Town of Happy Valley-Goose Bay, 2017), which increases the amount of bulk food packaging waste sent to the landfill. This places communities in a difficult position where they collect disproportionately more waste from some areas, but generally opt not to impose extra fees out of concern that residents will dispose of waste illegally (Harris Centre, 2017). However, the Town of Happy Valley-Goose Bay notes that it is not uncommon for waste to be dumped at the landfill entrance outside of business hours when the gate is closed.

A number of factors, including high retail prices, isolation, and low household income contribute to high levels of landfill harvesting (colloquially known as "scavenging"). Despite being illegal, landfill harvesting practices are common at the Happy Valley-Goose Bay municipal landfill and in small communities across the northeastern coast. Reclamation of commercial wastes like lumber or construction supplies is also common, but this unfolds differently because it is more predictable. For example, once a week a company may make materials available for public collection, which assists interested parties in a safe and planned transfer of reused materials.

At the provincial level, since 1996 waste diversion and recycling programs in Newfoundland and Labrador have been funded and managed through a Crown agency, the Multi-Materials Stewardship Board (MMSB). The MMSB is funded by levies on beverage containers and tires, as well as by the sale of recyclable materials collected under its programs (MMSB, 2017).

Waste management is not solely a government responsibility. It requires household- and community-level commitments as well, as noted by the Labrador Inuit Association study in Nain (1995). Happy Valley-Goose Bay residents are active contributors to waste management in many ways, partly through participation in initiatives led by the municipality or the Multi-Materials Stewardship Board, but also through implementing individual micro-level solutions for waste diversion, such as household composting. Further, when government-led services are perceived as unsatisfactory, residents may also come together to create 
larger, community-level initiatives. One such example is the Happy Valley-Goose Bay Recyclers group, which began in early 2017 in order to collect recyclable materials that otherwise would have gone to the municipal landfill. Initially, the group directed the recyclable material to a recycling plant in Norris Arm on the island of Newfoundland, part of the province south of Labrador, although recently the group has been able to successfully divert recovered metals to a nearby scrapyard. This group recognizes the economic barriers to a municipal-scale recycling program, but invites those for whom recycling is a strong priority to donate the requisite time and money to make recycling possible on a smaller scale.

As of May 2018, the group's Facebook page had 510 members, and they report thirty dedicated households whose donations and droppedoff recyclables have established the feasibility of the model, provided that residents who use the service continue to remain willing to fund it. This group is hosted without cost in a large storage shed owned by a local small business, Voisey's Bakery, and relies upon volunteer labour to accept, sort, and palletize recyclable materials. Non-metal materials are forwarded by a trucking service to a transfer station at Deer Lake in Newfoundland, over $957 \mathrm{~km}$ of road and a $36 \mathrm{~km}$ ferry, where they are fed into the processing stream for recycling at the plant in Norris Arm. The town's remoteness and the scarcity of retailers leads to unusually high rates of online shopping (Barker, 2017), producing a large volume of cardboard in particular.

Benefits identified by the group are above and beyond the usual advantages of waste diversion, and they include the education of children and the furtherance of a culture of environmentalism. Organizers have pursued funding opportunities with the municipality, provincial government, and local businesses, and an account has also been set up whereby residents locally dropping off beverage containers for the provincial MMSB recycling program can have the refunds donated to the Happy Valley-Goose Bay Recyclers group. They state that the chief limitation for the program is one of scale, as there is limited potential for expansion without significant infrastructure acquisitions.

\subsection{Results from Nain: Waste Management in Remote, Self-Contained Communities}

One economic advantage enjoyed by Happy Valley-Goose Bay with respect to waste management, and compared to many other northern locations, is its connection to the continental road network. Recognizing that waste management also presents challenges specific to rural northern 
communities that are accessible only by air and sea, it is worthwhile to extend our consideration secondarily to the community of Nain, Labrador. As a result of their remote location and long travel distances, the coastal communities of Labrador face complex challenges that are somewhat different from the Happy Valley-Goose Bay region within Labrador (Harris Centre, 2017; Storey et al., 2017; Neil, 2017). Despite its small population, the Labrador coast is a diverse region, and no single community can be taken as typical. However, since many challenges and opportunities are common across communities, an overview of the waste flows of Nain, for instance, will provide insights into waste management processes across remote communities throughout Labrador and the North.

With a population of 1,125 (Statistics Canada, 2017), Nain is the largest of the five communities in the Labrador Inuit Land Claims Area, under the regional jurisdiction of the Nunatsiavut Government. It was also the site of a 1995 case study in Inuit community waste management, conducted in partnership by the Inuit Tapirisat of Canada and the Labrador Inuit Association (Harris, 1995). It provides an example of a community in which waste management has been a recognized priority for some time. As noted in the case study, waste management is a community responsibility, shared by local residents and requiring leadership from local government (i.e., regionally the Nunatsiavut Government, and municipally the Nain Inuit Community Government or NICG).

Municipal operations including solid waste management are the responsibility of the NICG, which operates a dump site and regular weekly residential and commercial garbage collection. The dump is sorted by waste stream (e.g., household wastes, automotives, appliances, oil drums, scrap metal), and since winter weather, permafrost, and the scarcity of topsoil make landfill burial impractical, combustible waste streams are processed by incineration. A photograph of the dump taken in May 2017 is presented in Appendix C.

Given the remoteness and ecological sensitivity of the area, as well as the reliance of the Inuit population on wildlife and foraging for food security, environmental concerns associated with the dump site have special significance. One challenge is its location near the ocean without lining or leachate remediation measures, potentially leading to impacts on aquatic ecosystems and human health. As in many rural landfills, terrestrial wildlife is also potentially affected, with wildlife scavenging resulting in potential contamination of the food web and increased risk of adverse human-wildlife contact. These concerns have been articulated by Bharadwaj et al. (2006) and Schiff \& Bernard (2018) as overarching 
issues within First Nations communities across Canada, which rely upon hunting and gathering country foods for their sustenance. For more discussion about country foods among First Nations communities across Canada, and in relation to Newfoundland and Labrador's population as a whole, please consult Van Oostdam et al. (1999) and Keske (2018), respectively. This is exacerbated by the lack of organic waste diversion since, on account of the cold climate, permafrost, and poor soils, composting for agriculture is not a major strategy. Harsh winters with heavy snowfall also lead to widespread litter, since snow and ice often block garbage bins and impede waste transportation causing inefficient roadside pick up and scattering of household waste by stray dogs and crows.

The processing of hazardous materials is another challenge, bringing with it risks and economic costs associated with local storage and transportation outside the community. Ammunition is a particular concern, especially given its prevalence in a community reliant on hunting, since its inclusion in household waste destined for incineration can potentially endanger workers, landfill users, and equipment. The 1995 case study also notes incoming waste from external mineral exploration projects and base camps, presumably related to the development of the Voisey's Bay nickel deposit. Today the mine and mill site manage their wastes independent of nearby Inuit and Innu communities, providing a contrasting example with Muskrat Falls in Happy Valley-Goose Bay, for a variety of geographical, political, and economic reasons.

Nain has adapted its waste management strategies at both the household and municipal government levels. The community participates in the provincial beverage container recycling program by way of the public schools, which accept bagged household recyclables and ship them by ferry to Happy Valley-Goose Bay, and use the proceeds for a student breakfast program. Municipal initiatives, partially springing from the 1995 case study, include public awareness campaigns via radio, social media, and word of mouth about the dangers of improper hazardous waste disposal and the health reasons to avoid household burning of garbage; annual spring cleanup efforts that employ low-income or unemployed residents and serve as economic development; and also waste reduction strategies such as becoming the first community in the province to institute a ban on retail use of plastic bags (CBC News, 2009). 


\section{Discussion}

4.1 Building Synergistic Waste Management Strategies to Address Waste Management Costs

Results of the qualitative research phase are consistent with other findings from the waste management and public utilities literature. There must be incentives for households and commercial operations to adhere to waste management practices so that community-wide societal benefits can be achieved. Specifically, the marginal costs to households and firms to participate in municipal waste programs (e.g., compliance with collection terms and conditions, such as frequency of collection and materials accepted), must be lower than the marginal costs of taking waste management into one's own hands (e.g., though illegal waste burning or dumping). Improper waste disposal, even from a small number of noncompliant individuals, has the potential for localized environmental damage that may result in human health consequences, like drinking water contamination (Fonkwe, 2016). Scientific evidence indicates that biodegradation rates are slower in these regions due to cold temperature and soil characteristics, which means that there is a longer organic decomposition rate compared to warmer climates. Within the Churchill River valley in particular, soils are derived mainly from glaciofluvial sands and silts, with pockets of organic soils in poorly drained areas and acidic, sandy soils elsewhere, including in Happy Valley-Goose Bay proper (Walker, 2012; Fonkwe, 2016) where soils have low organic content and little ability to immobilize either nutrients (Abedin, 2015) or pollutants (Abedin, 2017).

However, the impacts that each household exerts onto the community or on the environment may not be immediately recognizable to households. Like other public utilities, including electricity generation (Fox-Penner, 2010), there are paradoxical tensions between ensuring that there is enough waste volume to facilitate municipal waste collection as a public service and providing incentives for individual households and firms to change their behaviour to achieve social goals. This creates perverse incentives for unsustainable waste management practices. Specifically, households may not see the value of reducing their waste volumes, in part because they are being encouraged to routinely supply waste as part of the weekly household waste removal cycle. Yet policymakers have expressed that they are uncomfortable with setting a limit on the number of bags allocated to each household out of concern that it will increase the incidence of illegal dumping. Thus, households receive positive reinforcement for sending unsorted waste streams for municipal 
collection, without a clear sense of how their waste affects environmental quality and the region's waste management practices in general.

In circumpolar and boreal climates, long transportation distances, lack of roads and transportation infrastructure, diffuse populations, and extended storage times raise waste management costs. This presents challenges even for conscientious advocacy groups like the Happy ValleyGoose Bay Recyclers group. Compared to central and southern regions of Canada, materials storage within the study region requires additional capacity due to extended winters. Storage space becomes increasingly scarce and pedestrian/vehicle access to storage areas becomes increasingly difficult during winter months and towards the end of spring. It is not uncommon for snow cover to remain for six consecutive months in the Happy Valley-Goose Bay population centre, and somewhat longer in other northern communities. The Gulf of St. Lawrence freezes, rendering coastal transportation difficult; the southern coastal ferry service runs from about July to October, depending on ice conditions. The harsh and unpredictable weather patterns require flexible scheduling and reactive accommodations that consequently prolong the implementation of projects across economic sectors, and even within households. Extreme weather patterns frequently cause disruptions to commerce and daily routines, despite the fact that residents are resilient and have grown accustomed to living with harsh and unpredictable weather events. As a result, it may not be feasible to store waste at on-site locations, or to transport materials elsewhere in a timely manner from the fall through spring months (October through April). These factors exert pressure on households to dispose of waste illegally by land or sea, a behaviour that has been noted in the past (Ritter, 2007), but that has also been demonstrated to take place at an increasing rate across the province after localized dump sites were closed (Harris Centre, 2017; Storey et al., 2017; Neil, 2017). Businesses also experience pressure to dispose of wastes for similar economic reasons. Drone technology has also documented a number of illegal waste sites in remote locations within Labrador, including those that are only accessible by off-highway vehicles (Allen, 2017).

Although environmental impacts and waste streams vary according to business size and scope, similar paradoxes exist for commercial and industrial wastes. In order to remain cost-competitive, maintain privacy, and to avoid conflict on potentially contentious resource projects, businesses may avail of disposal opportunities that are outside of the municipal waste infrastructure. By way of example, at least five controlled burns of waste wood and cardboard took place at the Muskrat Falls 
hydroelectric project during the first four months of 2017 (Barker, 2017), possibly in response to a $25 \%$ increase in municipal landfill tipping fees for non-residents. If waste sorting and processing from the Muskrat Falls project were coordinated with the Town of Happy Valley-Goose Bay, there might be added momentum to the community's overall waste sorting and processing practices. This may facilitate the development of additional infrastructure (e.g., a lined landfill) or other innovative means of waste management, like biogas capture.

\subsection{Policies that Address Public Health Risks While Recognizing the}

Practicalities of Waste Management in the North

Although we have summarized observations of waste management processes in Happy Valley-Goose Bay and a self-contained community on the northeastern coast, we haven't assessed the frequency or scope of these practices across the region or the North in general. Until these more detailed assessments take place, we recommend the use of the precautionary principle for setting new waste management policies. The precautionary principle essentially supports taking preventive action in the face of uncertainty and shifts the burden of proof to the proponents of an activity, while exploring a wide range of alternatives to possibly harmful actions.

We believe that the precautionary principle is particularly important for informal waste recovery practices. Landfill and curbside harvesting are realities in the rural Canadian North, although it is difficult to ascertain the scale and scope of the waste streams recovered and the household prevalence of participation. Many of the activities are illegal and are likely underreported (Barker, 2018). However, acknowledging that these activities are common practice is a first step towards the goal of facilitating a safe environment for waste recovery and reuse, while planning a vision of other sustainable, safe waste management programs.

As previously discussed, many households already store wastes for an annual spring cleanup and engage in curbside waste harvesting. Since the public is already accustomed to these practices, there is opportunity to expand these programs during different times of the year. For example, a second fall cleanup event, combined with a dedicated storage unit for sorted waste materials, could provide households with the option to access the materials and to repurpose these at other desirable times (e.g., preparation for the December holiday season and February Carnival celebrations). 
Sorting and organizing the landfill spaces to allow for specific waste streams (e.g., auto parts or furniture) would guide harvesters to more specific locations and times that would involve less contact with heavy equipment. As previously mentioned, additional labour force training to facilitate these sorting practices could include community outreach programs that would facilitate improved matching and sorting processes. It may also be possible for the provincial or federal governments to provide financial incentives to divert some wastes (e.g., plastic bottles or appliances) away from communities, but return revenues from bottle collection back to the communities of origin.

From a practical perspective, the province might consider creating legislation that would essentially indemnify the municipalities for facilitating waste trading and create more waste bartering/trading opportunities through the waste collection, sorting, transportation, and sorting processes. This may be a good place to start, though the implications of implementing such a policy would obviously require its own research study. As shown by Keske and Loomis (2008), there is some evidence to suggest that these policies work for natural resources on multi-purpose lands in rural communities.

\subsection{Quantitative Research Phase}

After results from the qualitative research phase were communicated to the Town of Happy Valley-Goose Bay, the community noted that it would consider adding an additional "fall" cleanup and other recommendations. However, more substantively, a subset of partners provided feedback about the waste priorities for the study's quantitative phase. Shortly after the completion of the qualitative research phase, we embarked on developing an enterprise budget for a prospective biochar production project co-located at the Muskrat Falls hydroelectric mega-project under construction by Nalcor Energy (Nalcor Energy, 2018). As described in Keske et al. (2018), the enterprise budget serves as a pilot study to assess the economic and technical feasibility of producing biochar from the biomass feedstock (primarily black spruce and balsam fir) that was cleared for transmission lines running to the new generating station at Muskrat Falls. The preliminary project focuses on the use of a mobile pyrolysis unit to reduce capital costs and take advantage of the log piles (pits) remaining after mass clear-cutting. The largest of these pits is located right next to the Muskrat Falls site, and for the purposes of the operation described in this report, biochar production would take place at the pit nearest Muskrat Falls, while Happy Valley-Goose Bay would be the business headquarters. 
The enterprise budget has been developed in an accessible spreadsheet format to facilitate adaptation to other project contexts. In sum, the results of this two-stage mixed methods research project reflect an exploration of the potential for biochar production operations to derive value from resource development project waste in remote regions across the North.

\section{Conclusions}

In conclusion, waste management in Canada's Circumpolar and Arctic North is complex. Moving forward, a multitude of socio-economic and climatic considerations must be considered in order to develop strategies, policies, and regulations commensurate with twenty-first century lifestyles, and to accommodate uncertainty associated with global climate change. However, optimistically speaking, attention to the development of a sustainable waste management program provides opportunity to foster community cohesion, drive innovation, and to address multiple social goals, like improved food security. We recognize that this qualitative phase of study has generated more research questions than we have answered. (By way of example, would increasing infrastructure and access to the landfill result in higher waste loads?) In the quantitative phase of the study, we decided to conduct an economic feasibility study on processing biomass into biochar. While this leftover biomass is a priority waste stream, a separate cost-benefit analysis is necessary in order to facilitate sustainable waste management of household wastes in both Happy Valley-Goose Bay and Nain. As others before us have noted, the mixed materials from household waste streams involves time intensive sorting and processing. As the community landfills approach capacity, it will be critical to have a better handle on the quantities of each material in order to evaluate whether policies will have a net improvement on environmental quality and waste management efficiency. Moreover, collaboration with larger organizations (e.g., Muskrat Falls or the nearby air base) has the potential to complement the municipality's effort by providing economies of scale. We urge the region to continue to seek partnerships with the hope of advancing these efforts.

We are optimistic that community grassroots organizations like the Happy Valley Goose Bay (HVGB) Recyclers Group will continue to build community awareness about the importance of sustainable waste management. Within one year, the organization's Facebook members increased by $40 \%$ to 510 members, and they have launched a new website (hvgbrecyclers.org). The group has moved to a collection model of the last Sunday of every month, with contributors giving $\$ 5$ or an hour of 
volunteer time to offset costs. Furthermore, in order to build additional synergy, the HVGB Recyclers are now officially affiliated with the Community Food Hub, which is a registered non-profit organization. They were also awarded a grant from the Mennonite Central Committee to offset some shipping and labour costs to make the project more sustainable in the long-term.

We have been fortunate to partner with the municipality of Happy Valley-Goose Bay, which has been actively pursuing research and innovation in waste management and environmental stewardship for many years. Their vision prompted us to engage in a holistic approach to conducting a waste management study of Labrador, and to position waste management in the Arctic as a resource issue that affects all of Canada. We assert that this holistic approach is a strength of the article; presenting results from the qualitative phase is a unique contribution to the waste management literature for circumpolar and boreal regions of the world. Furthermore, the presence of one of our authors in his hometown of Nain serves to ground truth many of the observations in each of the respective study areas, and it provides better insight into the different areas of Labrador in relation to one another. In future publications, we hope to be able to provide an update on the economic and social feasibility of implementing several of the policies suggested in the article, with the hope of improving the environmental and social sustainability of Labrador communities as a whole.

\section{Acknowledgements}

This work was supported by a sub-contract award from "Resources and Sustainable Development in the Arctic (ReSDA)" (2011-2017) [grant number 412-2011-1006] administered through the Labrador Institute at Memorial University of Newfoundland. ReSDA is a Major Collaborative Research Initiative funded by Canada's Social Sciences and Humanities Research Council. The authors gratefully acknowledge the community partners who prompted the project, and without whom it could not have been possible: Frank Brown, Julianne Griffin, Samantha NoseworthyOliver, and Anatolijs Venovcevs at the Town of Happy Valley-Goose Bay; Mike Hickey of Hickey Construction; and Tammy Lambourne and Marina Biasutti-Brown of Healthy Waters Labrador. Credit is also due to Labrador Institute colleagues Dr. Ron Sparkes, Dr. Joinal Abedin, and Nathaniel Pollock, for insights and direction throughout the research process. The authors also appreciate the suggestions of three anonymous reviewers and the editor, whose input improved the clarity and focus of the paper. 


\section{Authors}

Catherine Keske is associate professor of management at Ernest and Julio Gallo Management Program, School of Engineering, University of California-Merced.

Morgon Mills is program coordinator, Labrador Institute, Memorial University of Newfoundland.

Laura Tanguay is junior research associate, Ernest and Julio Gallo Management Program, School of Engineering, University of California-Merced.

Jason Dicker is research assistant, Labrador Institute, Memorial University of Newfoundland.

\section{Appendices}

Appendix A. Aerial photograph of Happy Valley-Goose Bay municipal landfill. Photo credit Jason Dicker

The Happy Valley-Goose Bay landfill is surrounded by wooded biomass. The Goose River flows nearby, which serves as a source to Mud Lake.

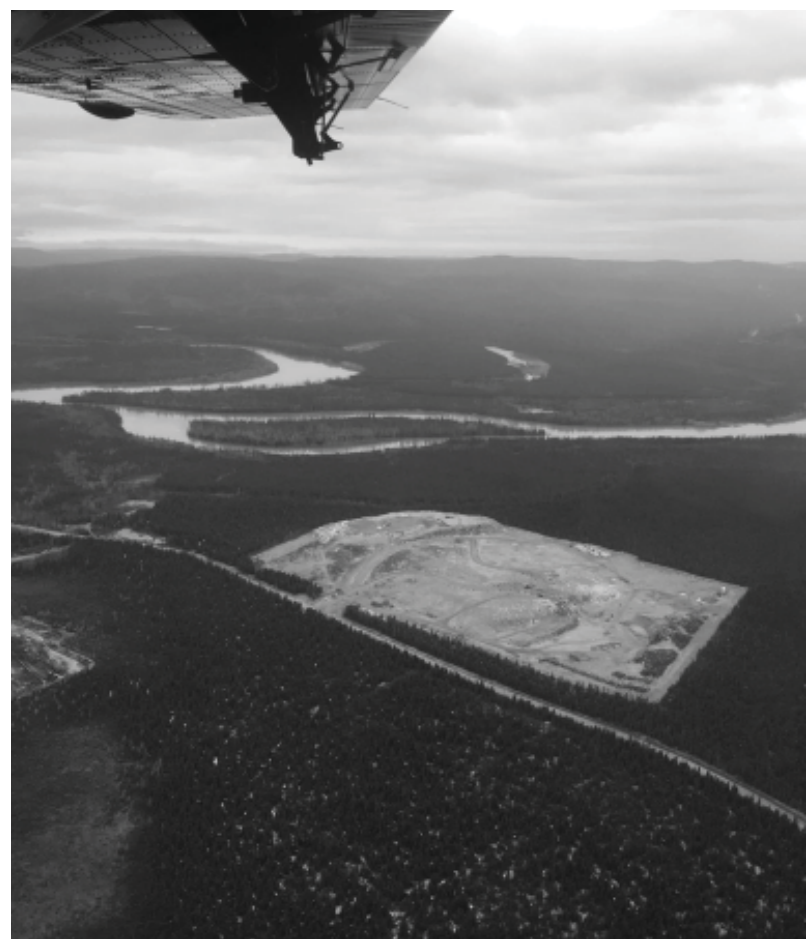


Appendix B. Happy Valley-Goose Bay Spring Cleanup, 23 June 2018. Photo credit Catherine Keske

As shown in the photographs, there can be a large quantity and an assortment of household items. Many households sort the wastes to make collection and trading easier for others.
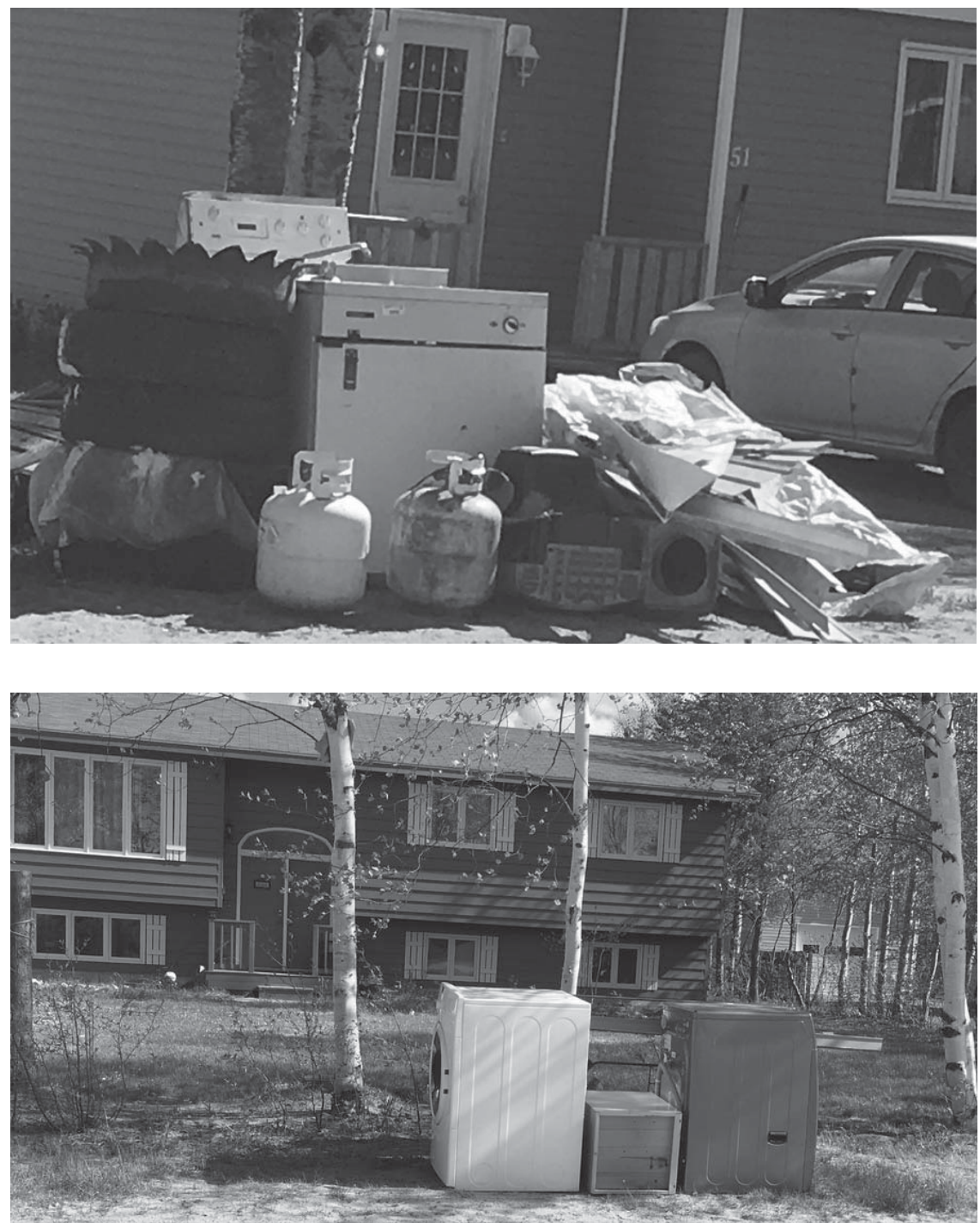
Appendix C. The Nain open landfill, 31 May 2017. Photo credit Jason Dicker

Even with the summer solstice imminent, snow remains along the narrow pathway to the open landfill. Water and waste accumulate into several sludge pools. Other sections of the landfill serve as a place where auto parts and appliances may be recovered. At the time these photos were taken, one of the researchers observed employees conducting an open burning at the landfill that had a noticeable effect upon air quality in the hamlet of Nain, where smoke tends to waft into town from over the hill. Although the skies are blue at the landfill, the air quality in town was smoky, filled with odour, with unclear visibility.
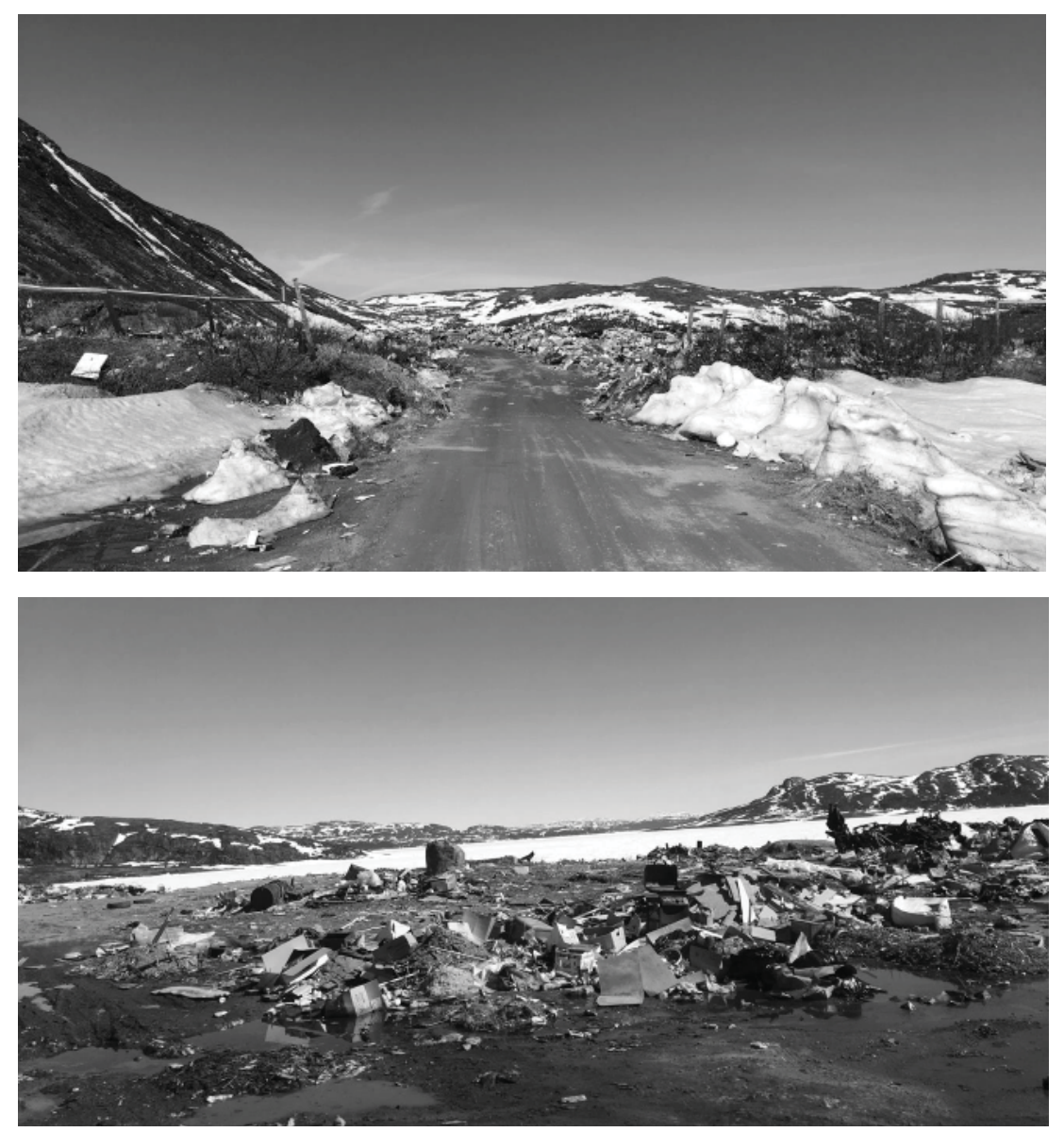


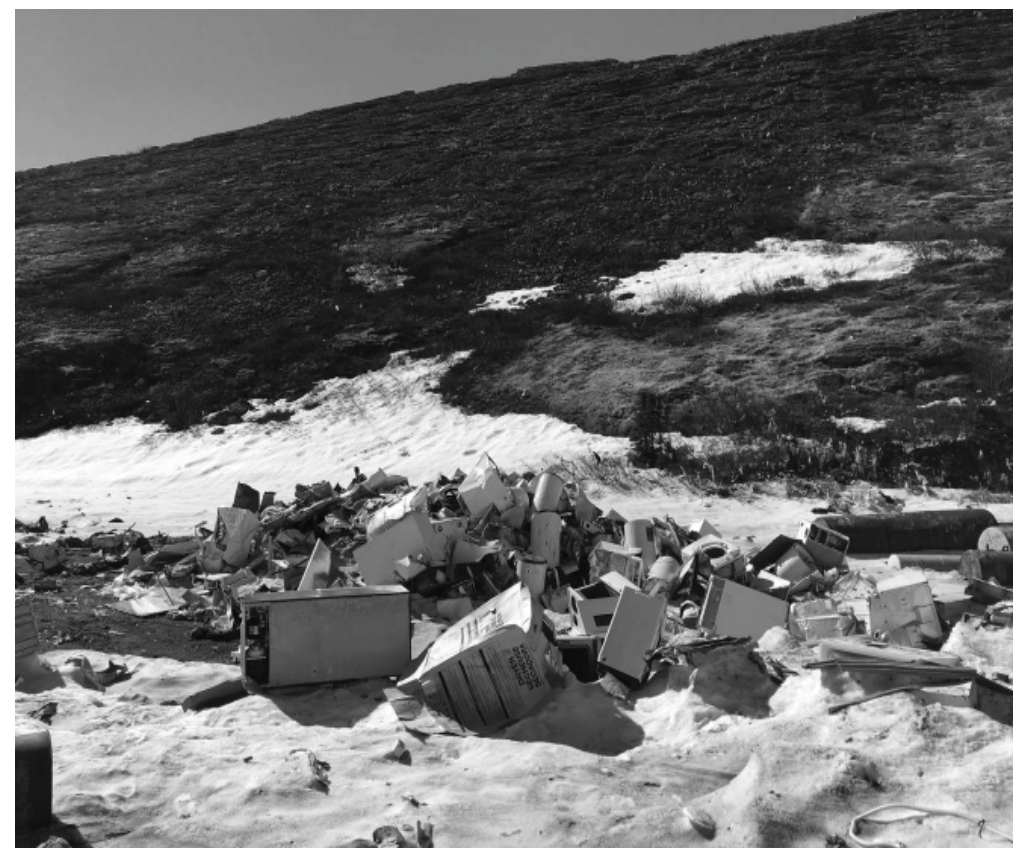

Appliance waste, and water heaters in particular, constitute a proportion of landfill waste. 
The last two photos demonstrate the realities of landfill harvesting during summer in Nain. The truck in the middle of the image provides a frame of reference. On 31 May 2017, at the beginning of summer, there is substantially more waste than on 23 August 2017, when volumes of waste have been collected after three months of summer, and before snowfall begins.
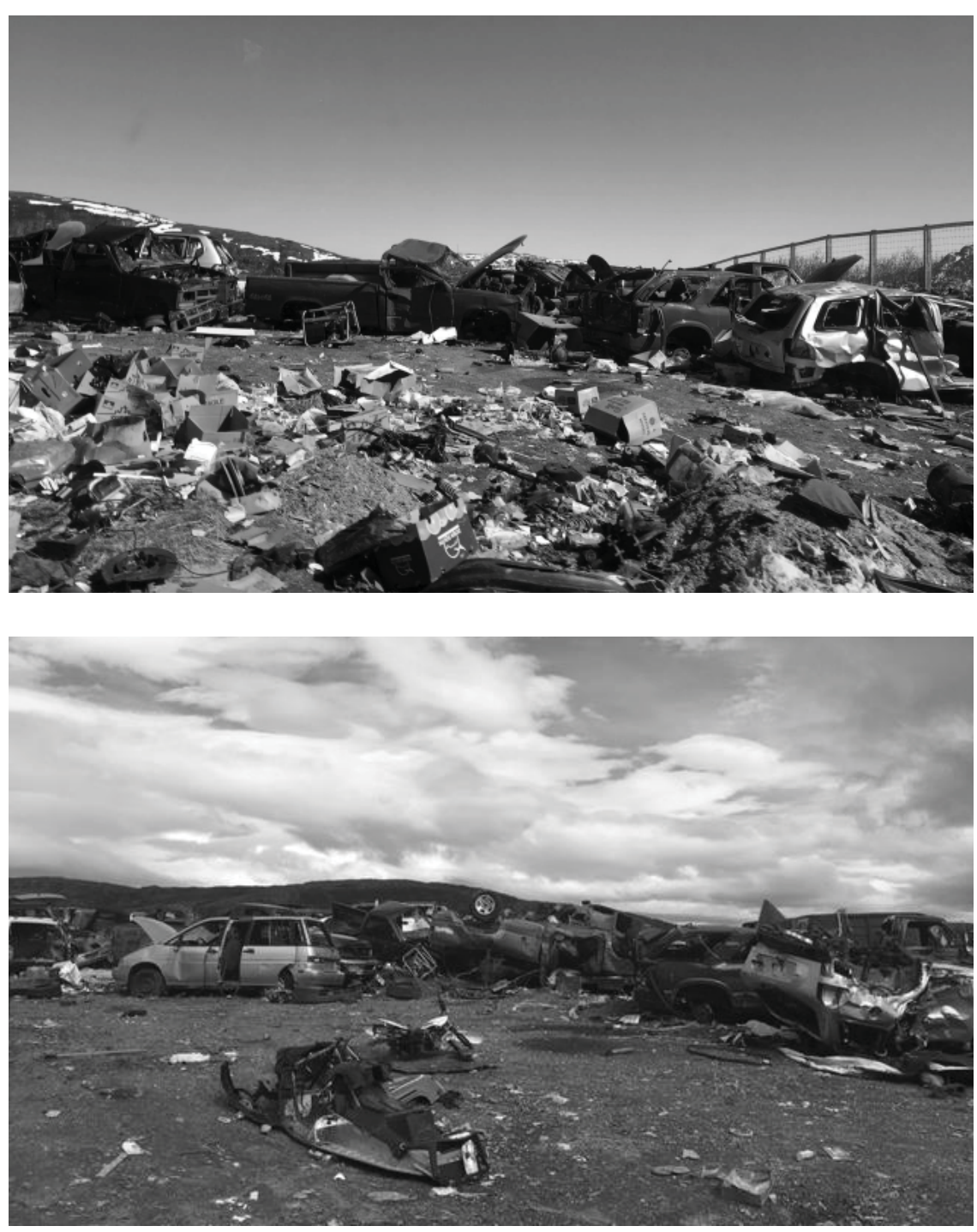


\section{References}

Abedin, J. (2017). Applying biochar to reduce leachate toxicity and greenhouse gas production in municipal solid waste (MSW). St. John's, NL: Harris Centre. Retrieved from https://www.mun.ca/harriscentre/reports/ABEDIN_15_16_ WASTE.pdf

Abedin, J. (2015). Potential for using biochar to improve soil fertility and increase crop production in the sandy soils of Happy Valley-Goose Bay, NL. Harris Centre, Memorial University of Newfoundland, St. John's, NL.

Allen, E. (2017, May 1). How can we use drone technology for research and learning in Labrador? Labrador Research Forum. Happy Valley-Goose Bay, NL, Canada. http://www.mun.ca/labradorinstitute/events/lrf/lrf_agenda.pdf

Barker, J. (2018, July 12). Scavengers at Happy Valley-Goose Bay landfill may soon face fines. CBC News. Retrieved from http://www.cbc.ca/news/can a d / newfoundland-labrador/ happy-valley-goose-bay-scavenging-tickets-1.4741132

Barker, J. (2017a). Burning waste at Muskrat Falls blasted by Goose Bay council. Retrieved from http://www.cbc.ca/news/canada/newfoundland-labrador/ nalcor-controlled-burns-muskrat-falls-1.4077195

Barker, J. (2017b). "It's Christmas every day": Happy Valley-Goose Bay post offices expanding to absorb boom in online sales. CBC News. Retrieved from http://www.cbc.ca/news/canada/newfoundland-labrador/ labrador-post-office-expansion-1.4005875

Bharadwaj, L., Nilson, S., Judd-Henrey, I., \& Ouellette, G. (2006). Waste disposal in First-Nations communities: The issues and steps toward the future. Journal of Environmental Health, 68(7), 35-39.

Canadian Broadcasting Corporation (CBC). (2008, August 5). Labrador town investigates water corrosion problems. Retrieved from http://www.cbc.ca/news/canada/newfoundland-labrador/ labrador-town-investigates-water-corrosion-problems-1.736176

Canadian Broadcasting Corporation (CBC). (2009, July 24). Nain votes to ban plastic bags. Retrieved from http://www.cbc.ca/news/canada/ newfoundland-labrador/nain-votes-to-ban-plastic-bags-1.813750

Canadian Press. (2014). Wood cut at Muskrat Falls a tough sell. Metro News Halifax. Retrieved from http://www.metronews.ca/news/canada/2014/09/18/woodcut-at-muskrat-falls-a-tough-sell.html

Capozza, K.L. (2002). Ditched drums and all. Bulletin of the Atomic Scientists, 58(1), 14-16.

Charron, D. (Editor) (2012). Ecohealth research in practice: Innovative applications of an ecosystem approach to health. Insight and Innovation in International Development 1, 255-271. https://doi.org/10.1007/978-1-4614-0517-7_21

Chouinard, A., Yates, C.N., Balch, G.C., Jørgensen, S.E., Wootton, B.C., \& Anderson, B.C. (2014). Management of tundra wastewater treatment wetlands within a 
lagoon/wetland hybridized treatment system using the SubWet 2.0 wetland model. Water, 6(3), 439-454.

Creswell, J.W. (2003). Research design: Qualitative, quantitative, and mixed methods approaches. Thousand Oaks, CA: Sage Publications.

Cunsolo Willox, A., Harper, S.L., Edge, V.L., Landman, K., Houle, K., \& Ford, J.D. (2013). The land enriches the soul: On climatic and environmental change, affect, and emotional well-being in Rigolet, Nunatsiavut, Canada. Emotion, Space, and Society, 6, 14-24.

Czepiel, P.M., Shorter, J.H., Mosher, B., Allwine, E., McManus, J.B., Harris, R.C., Kolb, C.E., \& Lamb, B.K. (2003). The influence of atmospheric pressure on landfill methane emissions. Waste Management, 23(7), 593-598.

Department of National Defence. (2014, March 7). The Distant Early Warning(DEW) Line remediation project. Retrieved from http://www.forces.gc.ca/en/news/ article.page?doc=the-distant-early-warning-dew-line-remediation-project/ hgq87xvs

Department of National Defence. (2009, March 2). Goose Bay remediation project. Retrieved from http://www.forces.gc.ca/en/news/article. page?doc=goose-bay-remediation-project/hnps1ufz

Department of National Defence. (2004, September 16). National Defence Completes Cleanup Project at Saglek, Labrador. Retrieved from http://www.forces.gc.ca/en/ news/article.page?doc=national-defence-completes-cleanup-project-at-sagleklabrador/hnocfnlc

Eisted, R., \& Christensen, T. (2013). Environmental assessment of waste management in Greenland: Current practice and potential future developments. Waste Management \& Research, 31(5), 502-509.

Felsberg, S. (2009). To burn or not to burn: Mud Lake and the provincial government debate the future of the village's incinerator. Labrador Life, 3(4), 24-27.

Fletcher, R. J. (1990). Military radar defense lines of northern North America: An historical geography. Polar Record, 26(159), 265-276. http://doi.org/10.1017/ $\underline{\mathrm{S} 0032247400011773}$

Fonkwe, M.L.D. (2016). A framework for better understanding drinking-water quality in Happy Valley-Goose Bay, Labrador: Implications for optimization and protection of municipally supplied water. St. John's NL: The Harris Centre, Memorial University of Newfoundland.

Fonkwe, M.L.D., \& Schiff, R. (2016). A survey of residents' perceptions of municipal drinking water in the community of Happy Valley-Goose Bay, Labrador. Happy Valley Goose Bay, NL: The Labrador Institute of Memorial University of Newfoundland.

Fox-Penner, P. (2014). Smart power anniversary edition: Climate change, the smart grid, and the future of electric utilities. Washington: Island Press.

Fraser, A.M. (2010) History of the participation by Newfoundland in World War II. In P. Neary \& M. Baker (Eds.) St. John's, NL: Centre for Newfoundland Studies. Retrieved from http://collections.mun.ca/PDFs/cns_publish/FraserManuscript.pdf 
Goose Bay Airport Corporation. (2018). History: Goose Bay Airport (About Us.) Retrieved from http://www.goosebayairport.com/history.asp

Government of Canada (2017). National Defence and the Canadian Armed Forces. Operation NUNALIVUT. http://www.forces.gc.ca/en/operations-canadanorth-america-recurring/op-nunalivut.page

Happy Valley Municipal Plan, 1972-1982. (1972) Provincial Planning Office, St. John's, NL.

Happy Valley-Goose Bay Municipal Plan, 1976. (1977). Provincial Planning Office, St. John's. NL.

Happy Valley-Goose Bay Municipal Plan, 1981-1991. (1981). Provincial Planning Office, St. John's, NL.

HarrisCentre.(2017). ThePopulationProject.MemorialUniversity of Newfoundland, St. John's, N. http://www.mun.ca/harriscentre/PopulationProject/

Harris, K., Lampe, J., \& Merkuratsuk, S. (1995). Waste management in Inuit communities: Pilot project to increase local involvement in addressing the problem of waste management. Ottawa, ON: Inuit Tapirisat of Canada.

Higgins, J., \& Callanan, L. (2006). Goose Bay. In Heritage Newfoundland and Labrador. Retrieved from http://www.heritage.nf.ca/articles/politics/goosebay-base.php

Hird, M.J. (2016). Waste legacies: Land, waste, and Canada's DEW Line. The Northern Review, 42, 173-195. http://journals.sfu.ca/nr/index.php/nr/article/ view/567

Indian and Northern Affairs Canada (INAC). (2005). Abandoned military site remediation protocol. http://www.nwb-oen.ca/public/other\%20documents/ Guidelines/050301\%20INAC\%20-\%20Abandoned\%20military\%20Site\%20 Remediation\%20Protocol-IMLE.pdf

Indigenous and Northern Affairs Canada (INAC). (2014). Northern contaminated sites program performance report 2012-2013. https://www.aadnc-aandc. gc.ca/eng/1406904610234/1406904831233

Indigenous and Northern Affairs Canada (INAC). (2016). Northern contaminated sites program. https://www.aadnc-aandc.gc.ca/eng/1100100035301/110010003 5302

Keske, C., Mills, M., Godfrey, T., Tanguay, L., \& Dicker, J. (2018). Waste management in remote rural communities across the Canadian North: Challenges and opportunities. Detritus Multi-disciplinary Journal for Waste and Residues 2, 63-77. https://doi.org/10.31025/2611-4135/2018.13641

Keske, C.M.H. (Editor). (2018) Food futures: Growing a sustainable food system for Newfoundland and Labrador. Institute of Social Economic Research (ISER) Books.

Keske, C. M., Hoag, D., McLeod, D.M., Bastian, C.T., \& Lacy, M.G. (2011). Using mixed methods research in environmental economics: The case of conservation easements. International Journal of Mixed Methods in Applied Business and Policy Research, 1(1), 16-28. 
Keske, C.M.H., \& Loomis, J.B. (2008). Regional economic contribution and net economic values of opening access to three Colorado Fourteeners. Tourism Economics, 14(2), 249-262.

Labrador Research Forum (2017, April 30-May 3). Happy Valley-Goose Bay, Labrador, Canada. http://www.mun.ca/labradorinstitute/events/lrf/

Lajeunesse, A. (2007). The Distant Early Warning Line and the Canadian battle for public perception. Canadian Military Journal, 8(2), 51-59.

Military Communications and Electronics Museum. (2002). The Pinetree Line web site. Retrieved from http://www.c-and-e-museum.org/Pinetreeline/homepage.html

Multi-Materials Stewardship Board. (2017). About MMSB. Retrieved from http:// mmsb.nl.ca/about-mmsb/

Nalcor Energy. (2009). Component studies: Air quality, timber resources and other, Timber resources, vol. 3. Environmental impact statement for the Lower Churchill Hydroelectric Generation Project St. John's, NL: Nalcor Energy.

Nalcor Energy. (2015). Muskrat Falls Project Community Liaison Committee project update. St. John's, NL: Nalcor Energy. Retrieved from https:// muskratfalls.nalcorenergy.com/wp-content/uploads/2013/03/Project-updateApril-14-2015.pdf

Neil, K. (2017, May 1). Public service delivery in Labrador. Labrador Research Forum poster presentation, Happy Valley-Goose Bay, NL.

Nunatsiavut Government. (2017). About Nunatsiavut Government: A leader for the Inuit People. Retrieved from http://www.nunatsiavut.com/government/ about-nunatsiavut-government/

Parlee, B. (2015). The social economy and resource development in Northern Canada. In C. Southcott (Ed.), Northern communities working together: The social economy of Canada's North (pp. 52-73). Toronto: University of Toronto Press,.

Parlee, B., \& Furgal, C. (2012). Well-being and environmental change in the Arctic: A synthesis of selected research from Canada's International Polar Year program. Climatic Change, 115(1), 13-34.

Rich, G., et al. (1984). Waste not, want not. Them Days: Stories of Early Labrador, 10(2), 57-63.

Ritter, T. (2007). Sharing environmental health practice in the North American Arctic: A focus on water and wastewater service. Journal of Environmental Health, 69(8), 50-5, 56, 58.

Ruscio, B.A., Brubacker, M., Glasser, J., Hueston, W., \& Hennessey, T.W. (2015). One health: A strategy for resilience in changing Arctic. International Journal of Circumpolar Health, 74. http://doi.org/10.3402/ijch.v74.27913

Schiff, R., \& Bernard, K. (2018). Food systems and Indigenous people in Labrador: Issues and new directions. In C. Keske (Ed.), Food futures: Growing a sustainable food system for Newfoundland and Labrador. Institute of Social Economic Research (ISER) Books. 
Southcott, C. (2015). Resource development and northern communities: An introduction. The Northern Review, 41,3-12. https://doi.org/10.22584/nr41.2015.001

Srinivasan, S., O'Fallon, L., \& Dearry, A. (2003). Creating healthy communities, healthy homes, healthy people: Initiating a research agenda on the built environment and public health. American Journal of Public Health, 93(9), 1446-1450.

Stantec. (2017). Final report: Implementation of the remedial action plan - Year 6, Former U.S. Military Site, Hopedale, NL. St. John's, NL: Department of Municipal Affairs and Environment.

Starostina, V., Damgaard, A., Rechberger, H., \& Christensen, T.H. (2014). Waste management in the Irkutsk Region, Siberia, Russia: Environmental assessment of current practice focusing on landfilling. Waste Management $\mathcal{E}$ Research, 32(5), 389-396.

St. Croix, R. (2002). Soils of the Happy Valley east area, Labrador: Soil survey report. St. John's, NL: Department of Forest Resources \& Agrifoods.

Statistics Canada. (2011). National household survey focus on geography series: Happy Valley-Goose Bay, Town. Retrieved from http://www12.statcan. gc.ca/nhs-enm/2011/as-sa/fogs-spg/Pages/FOG.cfm?lang=E\&level=4\&GeoCo de $=1010025$

Statistics Canada. (2017). Census profile, 2016 census. Retrieved from http:// www12.statcan.gc.ca/census-recensement/2016/dp-pd/prof/index.cfm

Storey, K., et al. (2017, May 2). The population project: Newfoundland and Labrador in transition, Labrador Research Forum presentation, Happy Valley-Goose Bay, NL.

Teddlie, C., \& Tashakkori, A. (2009). Foundations of mixed methods research: Integrating quantitative and qualitative approaches in the social and behavioral sciences. Thousand Oaks, CA: Sage Publications.

Van Oostdam, J., et al. (1999). Human health implications of environmental contaminants in Arctic Canada: A review. Science of the Total Environment, 230(1), 1-82. https://doi.org/10.1016/j.scitotenv.2005.03.034

Waldron, I.R.G. (2015). Findings from the series of workshops "In whose backyard?-Exploring toxic legacies in Mi'kmaw and African Nova Scotian communities." Environmental Justice, 8(X), 1-5. https://doi.org/10.1089/ env.2014.0034

Walker, T. (2012). Properties of selected soils from the sub-Arctic region of Labrador, Canada. Polish Polar Research, 33, 207-224. https://doi.org/10.2478/ v10183-012-0013-4

Zagozewski, R., Judd-Henrey, I., Nilson, S., \& Bharadwaj, L. (2011). Perspectives on past and present waste disposal practices: A community-based participatory research project in three Saskatchewan First Nations communities. Environmental Health Insights, 5, 9-20. https://doi.org/10.4137/EHI.S6974 